\title{
Pre Extension Demonstration of Tef Technologies at Midlands of Guji Zone, Southern Oromia, Ethiopia
}

\author{
Kebede Basha ${ }^{1, ~}$, Amare Girma ${ }^{2}$, Korji Dembi ${ }^{1}$ \\ ${ }^{1}$ Bore Agricultural Research Center, Agricultural Extension Team, Bore, Ethiopia \\ ${ }^{2}$ Department of Rural Development, Haramaya University, Dire Dewa, Ethiopia
}

Email address:

bsshkbd@gmail.com (K. Basha), raggasaaamare@gmail.com (A. Girma), korjidembi@gmail.com (K. Dembi)

${ }^{*}$ Corresponding author

\section{To cite this article:}

Kebede Basha, Amare Girma, Korji Dembi. Pre extension Demonstration of Tef Technologies at Midlands of Guji Zone, Southern Oromia, Ethiopia. International Journal of Energy and Environmental Science. Vol. 6, No. 5, 2021, pp. 116-121. doi: 10.11648/j.ijees.20210605.11

Received: August 10, 2021; Accepted: August 21, 2021; Published: September 6, 2021

\begin{abstract}
Midland area of Guji zone was potential for tef production. However, the productivity of the crop is below its potential at farm level due to lack of improved varieties. To solve this problem demonstration of improved tef varieties were initiated to evaluate yield performance, evaluate profitability of the improved tef technologies and assess farmers' feedbacks for further development of tef production during 2018/19 and 2019/20 years. Three potential districts were selected based on their tef potential production. From each district two kebeles were selected. 32 experimental farmers were used for this demonstration. Dagim and Tesfa improved varieties were demonstrated with standard check on $10 \mathrm{mx} 10 \mathrm{~m}$ area. A seed rate of $10 \mathrm{~kg} / \mathrm{ha}$ by a spacing of $20 \mathrm{~cm}$ between rows, drilling of tef in the line of rows and $121 \mathrm{~kg} / \mathrm{ha}$ of NPS fertilizer was used. Descriptive statistics, one way ANOVA, General Linear Model, qualitative and cost benefit analysis were used to analyze the data. Higher yield (19.06 qt/ha) was obtained from Dagim variety while Tesfa generated $14.09 \mathrm{qt} / \mathrm{ha}$. Lower yield (8.9 qt/ha) was harvested from the standard check. The result of one way ANOVA showed that there was a significance difference in Tesfa variety production at the three districts. The result of the Tukey test indicated that there was a significant difference between Shakiso and Adola district $(\mathrm{p}=0.012)$ with Shakiso experimental farmers harvested on average 2.77 quintals of Tesfa more than Adola experimental farmers. The cost benefit analysis result showed that 38,042, 24,464 and 8,058 ETB/ha was obtained from Dagim, Tesfa and Tseday varieties respectively. Early mature, market demand and high yield of tef variety was preferred by farmers in the study area. Farmers selected Tesfa and Tseday as they were slightly early mature variety than Dagim. Tesfa and Tseday varieties were lower yield than Dagim variety. Based on the preference of the farmers, grain yield obtained and returns Dagim and Tesfa varieties were recommended for scaling up in the study area and similar agro-ecologies.
\end{abstract}

Keywords: Dagim, Demonstration, Guji, Tef, Tesfa, Variety

\section{Introduction}

Agriculture contributes $34.1 \%$ to the GDP, employs some $79 \%$ of the population, accounts for $79 \%$ of foreign earnings, and is the major sources of raw material and capital for investment and market [1]. Tef (Eragrostis tef) is an ancient tropical cereal crop that has its center of origin and diversity in the northern Ethiopian highlands from there it is believed to have been domesticated [2].

Tef is a cereal crop comprehensively cultivated in Ethiopia with annual coverage of about 2.8 million hectares. This crop has special useful traits both for producers and consumers.
For instance; i) tef is tolerant to extreme environmental conditions (tef is resisted to many biotic and abiotic stresses); ii) the seeds are not attacked by storage pests; iii) the seeds are gluten-free (safe for diabetics as well as sufferers of immune reactions to wheat gluten) and rich in minerals and protein [3].

The most common utilization of tef in Ethiopia is the fermented flatbread called injera [4]. Other utilizations of tef include local alcoholic beverages called tela and katikala, and porridge [5]. Additionally, tef plant residues could be used as fodder for livestock, and often incorporated as construction materials [6]. Tef is an economically superior commodity in Ethiopia. It often commands a market price 
two to three times higher than maize, the commodity with the largest production volume in the country [7], thus making tef an important cash crop for producers [5]. Nevertheless, the national yield per unit area $\left(1.6 \mathrm{t} \mathrm{ha}^{-1}\right)$ still remains low, quite large proportions of tef producing farmers still use unimproved local cultivars, bottleneck problems like lodging have not been alleviated, and the demand for high-quality tef planting seed has become increasingly high [8].

Tef is the main crop produced in the midland areas of Guji Zone. Usually the crop is sown after other crops (maize and haricot bean) are harvested. The crop is produced for both household consumption and cash crop. Tef could be produced in both seasons (meher and belg) hence the crop is used for double cropping purpose which increases farmers' production and income [9]. Despite double cropping of tef in the area many farmers were not food secured and only few model farmers used tef for their daily local food while other farmers were intended to sale their existing low product to the market rather than for household consumption. This is due to the use of low yielder varieties and lack of climate smart varieties (drought tolerant and early mature varieties) which can produce surplus production for farmers [10]. In Ethiopian agricultural system most agricultural research technologies reach the end user in the form of pre extension demonstration, pre scaling up/out and large scale demonstration. Their difference is based on the scope of participants on the activity, land size and the intended objective. In pre extension demonstration, few participants will done research on small areas and based on the result of pre extension demonstration, further research will be conducted in the form of pre scaling up/out and the large scale demonstration will be followed for anticipated objective of released agricultural research technologies. Many tef varieties were released by agricultural research centers. However, best varieties and their recommended packages were not intensively practiced in midland areas of Guji Zone due to lack of demonstration approach (learning by doing) of improved varieties on farmers field. Therefore, demonstration of improved varieties such as Dagim and Tesfa which were drought tolerant, early mature and high yielder is important for farmers producing tef in midland areas of Guji Zone. The specific objectives of this activity were to create awareness on the improved tef technologies in midland area, to evaluate yield performance and profitability of the improved tef technologies under farmers' conditions and to assess farmers' feedbacks for further development of tef production.

\section{Materials and Methods}

\subsection{Description of Study Areas}

Adola Rede district is 468KM away from the Addis Ababa to the South. The district is bordered by Ana Sora district in the North, Wadera district in the South and Odo Shakiso in the West and Girja district in the East directions. The district has altitude range of 1350-2340 meter above sea level, annual mean of $1000 \mathrm{~mm}$ rainfall and annual average of $28^{\circ} \mathrm{C}$ of temperature. Mixed farming, mining and forest product production are the major livelihood of Adola Rede farmers. Adola district has diverse agro-ecologies which are suitable for production of different crops. The rainfall pattern of the district is bimodal for lowland and midland areas and unimodal for highland parts. Sandy, clay and silt are the major soils of Adola Rede district. The major crops produced in the area include maize, tef, haricot bean, chat, coffee and the others $[11,12]$. Natural minerals are mainly found at Odo Shakiso district. Farmers of the district practiced mixed farming (crop and livestock). Tef, maize, haricot bean and coffee were the major crop production in the area. The district is also known by different fruits and vegetables. Most rural youth of Odo Shakiso district engaged on extraction of different minerals. Wadera district is one of agro pastoral areas of Guji zone. The district is well known by livestock rearing and livestock production is the major farming activity of the district. Tef, maize, haricot bean crops were mainly produced in the district.

\subsection{Sites and Experimental Farmers Selection}

With collaboration of District Agriculture and Natural Resource Office two kebeles (sites) were selected from each district. In each district the site for demonstration was selected based on tef producing potential and accessible for monitoring purpose. Farmers were selected based their interest to grow improved tef varieties and access to land. Accordingly, during both production of 2018/19 and 2019/20 years 32 farmers (nine women) were selected as experimental farmers for demonstration of tef varieties.

\subsection{Experimental Design and Treatments}

Land was ploughed two to three times after maize is harvested from the land. Plantation was early September. Two improved tef varieties namely Dagim and Tesfa were demonstrated during 2018 and 2019 production seasons. For comparison standard check namely Tseday variety was sown along the improved varieties. A plot area of $10 \mathrm{mx} 10 \mathrm{~m}$ was used for each treatment. Seed and fertilizer rate were other technologies demonstrated along with improved tef varieties. The recommended seed rate of $15 \mathrm{~kg} / \mathrm{ha}$ was sown by a spacing of $20 \mathrm{~cm}$ between rows and drilling of tef in the line of rows. $121 \mathrm{~kg} / \mathrm{ha}$ of NPS fertilizer was applied during sowing. Hand weeding was done by experimental farmers. Harvesting and threshing was done manually by experimental farmers with technical support of respective Development Agents assigned at each kebele and Agricultural extension researchers of Bore Agricultural Research Center.

\subsection{Methods of Data Collection and Analysis}

Personal observation, measurements and interview were applied to collect yield data, costs of production, income generated and farmers' feedback. Descriptive statistics and qualitative analysis of farmers' assessment/feedback was used to analyze the data. One way ANOVA and General 
Linear Model were used to identify mean variation among treatments. Cost benefit analysis was used to estimate economic returns on demonstrated varieties.

\section{Results and Discussion}

\subsection{Capacity Building on Tef Production}

The main intention of agricultural extension is to enhance the knowledge and skills of farmers on recommended agricultural technologies [13]. Hence, in order to capacitate the farmers' knowledge on tef production trainings were given for selected experimental farmers and nonexperimental farmers, Development Agents (DAs), and Subject Matter Specialists (SMSs). Exchange visit were organized to enhance farmer to farmer learning on the production and management of tef. Cereal, Extension research team and other stakeholders (Offices of Agriculture and Natural Resource) actively participated by sharing their experience and knowledge during training and Exchange visit organized. Table 1 shows number of farmers, DAs, SMSs and other participants who attended training and Exchange visit on tef demonstration.

Table 1. Capacity building methods and number of participants for demonstration of tef.

\begin{tabular}{|c|c|c|c|c|}
\hline \multirow{2}{*}{ Capacity building methods } & \multirow{2}{*}{ Participants } & \multicolumn{3}{|c|}{ Number of participant } \\
\hline & & Male & Female & Total \\
\hline \multirow{3}{*}{ A. Training } & Farmers & 60 & 30 & 90 \\
\hline & Development Agents & 6 & 2 & 8 \\
\hline & Subject Matter Specialists & 5 & 1 & 6 \\
\hline \multirow{3}{*}{ B. Exchange visit } & Farmers & 15 & 5 & 20 \\
\hline & Development Agents & 4 & 1 & 5 \\
\hline & Subject Matter Specialists & 5 & - & 5 \\
\hline
\end{tabular}

\subsection{Yield Performance of Demonstrated Tef Varieties}

Higher yield was obtained from Dagim variety (19.06 $\mathrm{qt} / \mathrm{ha})$ and Tesfa (14.09 qt/ha). Lower yield (8.9 qt/ha) was harvested from the standard check which was Tseday. The yield obtained from both improved varieties (Dagim and Tesfa) were greater than the yield of pre-scaling up of teff varieties at study area $(13.2452 \mathrm{qt} / \mathrm{ha}$ and $13.037 \mathrm{qt} / \mathrm{ha}$ for Boset and Tseday respectively [14]. Similarly, yield obtained from Dagim Variety was greater than national average yield of tef $17.56 \mathrm{qt} /$ ha [15]. There was high variation of yield across the district. This could be due to difference of management practices of experimental farmers, soil and environmental conditions [16]. Higher yield of Dagim variety was obtained from Shakiso district (20 qt/ha) followed by Adola district (18.53 qt/ha). Tesfa variety also gave more yield (15.53 qt/ha) at Shakiso district than the other districts. Table 2 shows the yield performance of improved and standard check tef demonstrated varieties.

Table 2. Mean yield of tef variety demonstrated $q$ t/ha.

\begin{tabular}{|c|c|c|c|c|}
\hline \multicolumn{2}{|c|}{$\begin{array}{l}\text { Name of districts where pre extension demonstration } \\
\text { conducted }\end{array}$} & \multirow{2}{*}{$\begin{array}{l}\text { Dagim variety Yield/ha } \\
18.5385\end{array}$} & \multirow{2}{*}{$\begin{array}{l}\text { Tesfa variety Yield/ha } \\
12.7692\end{array}$} & \multirow{2}{*}{$\begin{array}{l}\text { Tseday variety Yield/ha } \\
8.5385\end{array}$} \\
\hline \multirow{5}{*}{ Adola } & Mean & & & \\
\hline & $\mathrm{N}$ & 13 & 13 & 13 \\
\hline & Std. Deviation & 2.06621 & 2.71274 & 1.61325 \\
\hline & Minimum & 16.00 & 10.00 & 6.00 \\
\hline & Maximum & 23.00 & 20.00 & 11.00 \\
\hline \multirow{4}{*}{ Shakiso } & Mean & 20.0000 & 15.5385 & 9.3077 \\
\hline & Std. Deviation & 3.58236 & 2.22169 & 1.49358 \\
\hline & Minimum & 16.00 & 12.00 & 7.00 \\
\hline & Maximum & 30.00 & 20.00 & 12.00 \\
\hline \multirow{4}{*}{ Wadara } & Mean & 18.1667 & 13.8333 & 8.8333 \\
\hline & $\mathrm{N}$ & 6 & 6 & 6 \\
\hline & Std. Deviation & .75277 & .98319 & 1.83485 \\
\hline & Minimum & 17.00 & 13.00 & 7.00 \\
\hline \multirow{5}{*}{ Total } & Mean & 19.0625 & 14.0937 & 8.9063 \\
\hline & $\mathrm{N}$ & 32 & 32 & 32 \\
\hline & Std. Deviation & 2.71124 & 2.55721 & 1.59352 \\
\hline & Minimum & 16.00 & 10.00 & 6.00 \\
\hline & Maximum & 30.00 & 20.00 & 12.00 \\
\hline
\end{tabular}

The one way ANOVA analysis (Table 3) showed that there is a significant difference (at 5\% level of significant) in Tesfa variety production among the three district of 32 experimental farmers (F-value 4.791 and $\mathrm{P}=0.016$ ). 
Table 3. ANOVA result.

\begin{tabular}{|c|c|c|c|c|c|c|}
\hline & & Sum of Squares & df & Mean Square & $\mathbf{F}$ & Sig. \\
\hline \multirow{3}{*}{ Dagim } & Between Groups & 19.811 & 2 & 9.905 & 1.381 & .267 \\
\hline & Within Groups & 208.064 & 29 & 7.175 & & \\
\hline & Total & 227.875 & 31 & & & \\
\hline \multirow{3}{*}{ Tesfa } & Between Groups & 50.347 & 2 & 25.173 & 4.791 & .016 \\
\hline & Within Groups & 152.372 & 29 & 5.254 & & \\
\hline & Total & 202.719 & 31 & & & \\
\hline \multirow{3}{*}{ Tseday } & Between Groups & 3.885 & 2 & 1.943 & .753 & .480 \\
\hline & Within Groups & 74.833 & 29 & 2.580 & & \\
\hline & Total & 78.719 & 31 & & & \\
\hline
\end{tabular}

P-value of Tesfa variety (.016) indicating significant difference between treatment groups (Dagim and Tseday varieties demonstrated at the three districts). The results from the one-way ANOVA do not indicate which of the three groups differ from one another and did not show at what district and by how much mean variation is existed in this study. Therefore, it is necessary to conduct post analysis (after ANOVA analysis). There are many analysis used for post analysis methods. General Linear Model (GLM)
Univariate can be used to identify variation among treatment than one way ANOVA. Since the assumption of homogeneity of variance is fulfilled (Equal Variances Assumed) the most commonly used test is the Tukey (HSD) test (Table 5). The result of the Tukey test indicated that there was a significant difference between Shakiso and Adola district $(\mathrm{p}=0.012)$ with Shakiso experimental farmers harvested on average 2.77 quintals of Tesfa more than Adola experimental farmers (Table 4).

Table 4. Multiple Comparisons (Tukey HSD).

\begin{tabular}{|c|c|c|c|c|c|c|}
\hline \multicolumn{7}{|c|}{ Dependent Variable: yield of Tesfa variety } \\
\hline \multirow{2}{*}{ (I) district } & \multirow{2}{*}{ (J) district } & \multirow{2}{*}{ Mean Difference (I-J) } & \multirow{2}{*}{ Std. Error } & \multirow{2}{*}{ Sig. } & \multicolumn{2}{|c|}{ 95\% Confidence Interval } \\
\hline & & & & & Lower Bound & Upper Bound \\
\hline \multirow{2}{*}{ Shakiso } & Adola & $2.77^{*}$ & .899 & .012 & .55 & 4.99 \\
\hline & Wadera & 1.71 & 1.131 & .302 & -1.09 & 4.50 \\
\hline \multirow{2}{*}{ Adola } & Shakiso & $-2.77^{*}$ & .899 & .012 & -4.99 & -.55 \\
\hline & Wadera & -1.06 & 1.131 & .620 & -3.86 & 1.73 \\
\hline \multirow{2}{*}{ Wadera } & Shakiso & -1.71 & 1.131 & .302 & -4.50 & 1.09 \\
\hline & Adola & 1.06 & 1.131 & .620 & -1.73 & 3.86 \\
\hline \multicolumn{7}{|c|}{ * The mean difference is significant at the. 05 level. } \\
\hline
\end{tabular}

Table 5. Test of Homogeneity of Variances.

\begin{tabular}{lllll}
\hline & Levene Statistic & df1 & df2 & \\
\hline Dagim & 2.407 & 2 & 29 & .108 \\
Tesfa & 1.390 & 2 & 29 & .265 \\
Tseday & .210 & 2 & 29 & .811 \\
\hline
\end{tabular}

Non significance value of each variety assures the assumption of equal variance

\subsection{Cost Benefit Analysis}

In terms of profitability, the cost benefit analysis result shows that an average a profit of 38,042, 24,464 and 8,058 ETB per hectare was obtained from Dagim, Tesfa and Tseday variety respectively. Dagim variety was more profitable than both Tesfa and Tseday at the study area. The average farm get price was 27.5 ETB for one kilogram of both improved varieties and 25 ETB for standard check (Tseday) variety. Total revenue was calculated by multiplying price by yield obtained $(\mathrm{TR}=\mathrm{Y} \times \mathrm{P})$, gross marginal rate were calculated by subtracting total variable cost from total revenue (GM=TRTVC) and the final profitability was calculating by subtracting total fixed cost from total gross marginal rate (Profit=GM-TFC). Cost of seed, fertilizer, land preparation, weeding, harvesting, and threshing were used as Total Variable Costs while cost of land was a Fixed Cost for used for cost benefit analysis.

Table 6. Cost benefit analysis of tef demonstrated varieties in ETB/ha.

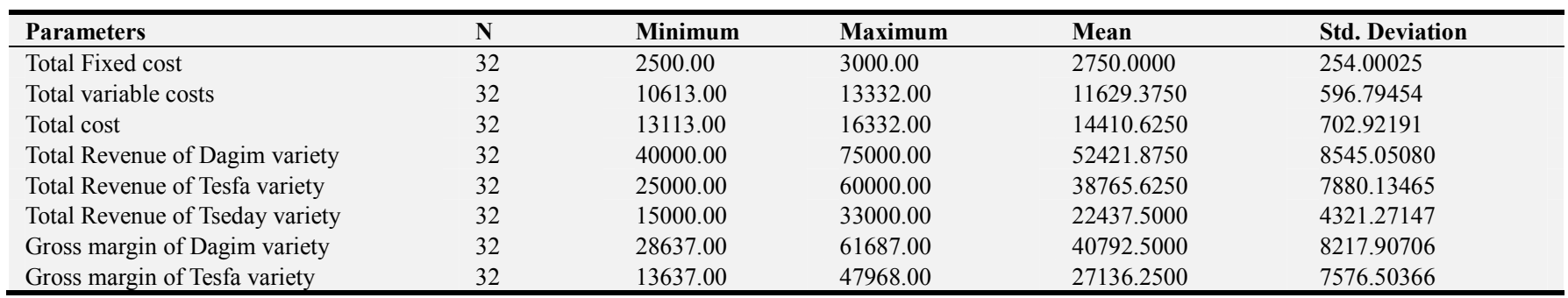




\begin{tabular}{lllll}
\hline Parameters & N & Minimum & Maximum & Mean \\
\hline Gross margin of Tseday variety & 32 & 4337.00 & 19668.00 & 10808.1250 \\
Profit of Dagim variety & 32 & 26137.00 & 59187.00 & 38042.5000 \\
Profit of Tesfa variety & 32 & 11137.00 & 44968.00 & 24464.3750 \\
Profit of Tseday variety & 32 & 1837.00 & 16668.00 & 8072.66572 \\
\hline
\end{tabular}

\subsection{Farmers' Preference on Tef Varieties}

During pre-extension demonstration of tef technologies farmers give sound feedbacks regarding demonstrated varieties. Farmers at study area have an experience of tef production and they used tef as household consumption, income generation and use its straw as a feed for livestock and house construction. Both improved varieties used for demonstration were white in color which demands the market Even though Tesfa and Tseday varieties were gave low grain yield compared to the Dagim variety they are early matured varieties with less rainfall than Dagim variety. The result of this demonstration was similar to [9] who revealed early mature the variety was preferred by farmers in their study area. Strong straw of Dagim variety can help the farmer for the purpose of house construction and the high grain yield and return can help farmers as income generation, food selfsufficient and increase their purchasing power of agricultural inputs.

\section{Conclusions and Recommendations}

Pre extension demonstration of improved tef varieties were conducted in midland districts of Guji zone. Dagim and Tesfa were demonstrated along standard check (Tseday) variety. Both Dagim and Tesfa varieties gave higher yield and profitable than standard check. Based on their white color which is preferred for both household and market demand Dagim and Tesfa were selected by farmers. Midland districts of Guji zone is characterized with the shortage of rainfall. Therefore, early mature tef variety was preferred by farmers. Farmers selected Tesfa and Tseday as they were slightly early mature variety than Dagim. Based on the preference of the farmers, grain yield obtained and returns both improved Dagim and Tesfa varieties were recommended for scaling up in the study area and similar agro-ecologies.

\section{Acknowledgements}

Authors would like to thank Oromia Agricultural Research Institute and Bore Agricultural Research Center for financial and facilities support respectively. Development Agents and farmers who devoted for the accomplishment of this demonstration were also acknowledged.

\section{References}

[1] Ministry of Agriculture (MOA) (2019). Transforming Ethiopian Agriculture: Power Point Presentation, Briefing for Agricultural Scholar Consultative Forum, April 2019, Addis Ababa.
[2] Demeke M, Marcantonio D (2013). Analysis of incentives and disincentives for tef in Ethiopia. MAFAP, SPAAA.

[3] Fikadu, Asmiro A, Wedu, Tsega D, Derseh, Endalew A. (2018) Review on Economics of Teff in Ethiopia. Open AccBiostat Bioinform. 2 (3). OABB. 000539. 2019. DOI: 10.31031/OABB.2018.02.000539

[4] Zhu F. Chemical composition and food uses of teff (Eragrostis tef). Food Chem 2018; 239: 402-15. [http://dx.doi.org/10.1016/j.foodchem.2017.06.101] [PMID: 28873585].

[5] Abraham R. Achieving food security in Ethiopia by promoting productivity of future world food tef: (2015) A review. Adv Plants Agric Res; 2 (2): 00045.

[6] Cheng A, Mayes S, Dalle G, Demissew S, Massawe F (2017) Diversifying crops for food and nutrition security. A case of teff. Biol Rev Camb PhilosSoc; 92 (1): 188-98. [http://dx.doi.org/10.1111/brv.12225.

[7] FAO. Analysis of price incentives for Teff in Ethiopia (2015) Technical notes series, MAFAP, by Assefa B. Demeke M., Lanos B, 2015 Rome.

[8] Solomon Chanyalew, Kebebew Assefa, Mitiku Asfaw, Yazachew Genet, KidistTolossa, Worku Kebede, Tsion Fikre, Nigussu Hussen, HabteJifar, Atinkut Fentahun, Kidu Gebremeskel, Girma Chemeda and Tegegn Belete (2017) Tef (Eragrostis tef) Variety "Dagim" Ethiop. J. Agric. Sci. 27 (2) 131-135.

[9] Basha Kebede and Dembi Korji (2017). Demonstration of improved teff varieties at selected midland districts of Guji zone, Oromia regional state, Ethiopia. Asian Journal of Agriculture and Rural Development, 7 (7), 131-135.

[10] Kebede B, Teshome G, Assefa K, Chimdessa O, Alemu S, et al. (2018) Participatory Evaluation and Selection of Improved Tef Varieties in Agro pastoral areas of Guji Zone, Oromia Regional State, Ethiopia. J AgriSci Food Res 9: 213.

[11] Basha Kebede, Dembi Korji, Girma Amare and Belachew Dabalo 2018 On Farm Demonstration and Evaluation of Improved Chickpea Varieties at Adola Rede, Guji Zone, Southern Oromia, Ethiopia. Innovative Techniques in Agriculture 2.6 (2018): 531-537.

[12] Girma Amare, Basha Kebede and Dembi Korji, "PreExtension Demonstration of Selected Lablab Varieties at Midlands of Guji Zone, Southern Oromia, Ethiopia.", International Journal of Research in Agriculture and Forestry, 7 (7), 2020, pp. 08-12.

[13] Basha, K., Dembi, K., Girma, A., 2021. Pre extension demonstration of improved potato at midland districts of Guji Zone, Southern Oromia, Ethiopia. Scientific Journal of Crop Science, 10 (2), 457-463.

[14] Basha Kebede, Dembi Korji and Girma Amare. "Pre-Scaling Up of Improved Tef Varieties at Adola Rede District, Guji Zone, Southern Oromia, Ethiopia". EC Agriculture 5.4 (2019): 178-183. 
[15] CSA (Central Statistical Agency). (2019). The federal democratic republic of Ethiopia central statistical agency agricultural sample survey, vol. 1, report on area and production of major crops, 589th statistical bulletin.
[16] Basha Kebede, Dembi Korji, Girma Amare. Pre Extension Demonstration of Adapted Oat Varieties at Midland Areas of Guji Zone, Southern Oromia International Journal of Animal Science and Technology. Vol. 5, No. 2, 2021, pp. 42-46. doi: 10.11648/j.ijast.20210502.13. 